\title{
Advancing phenology in Europe's last lowland primeval forest: non-linear temperature response
}

\author{
Tim H. Sparks ${ }^{1,4, *}$, Bogdan Jaroszewicz ${ }^{2}$, Marta Krawczyk $^{3}$, Piotr Tryjanowski ${ }^{3}$ \\ ${ }^{1}$ NERC Centre for Ecology and Hydrology, Monks Wood, Abbots Ripton, Huntingdon, Cambridgeshire PE28 2LS, UK \\ ${ }^{2}$ Białowieża Geobotanical Station, Faculty of Biology, University of Warsaw, Sportowa 19, 17-230 Białowieża, Poland \\ ${ }^{3}$ Department of Behavioural Ecology, Faculty of Biology, Adam Mickiewicz University, Umultowska 89, 61-614 Poznań, Poland
}

${ }^{4}$ Present address: 68 Girton Road, Girton, Cambridge CB3 0LN, UK

\begin{abstract}
We analysed phenological observations of first flowering and peak flowering dates of 7 species of woodland herbs in the Białowieża National Park (Poland), Europe's last remaining lowland primeval forest and a World Heritage Site, during 1964-2007. There was substantial evidence for an advance in both first and peak flowering dates and flowering was closely related to temperature, which had risen substantially in this area. Similar advances have been reported from elsewhere, but typically from human-modified habitats. A comparison with contemporary data from the UK suggests that flowering was both later and less responsive in Poland. Examination of the data from the 2 countries over a wide range of temperatures hints at possible non-linear temperature responses; thus estimates of phenological change from linear regression may seriously underestimate changes which may occur in Białowieża in the future.
\end{abstract}

KEY WORDS: Flowering $\cdot$ Temperature response $\cdot$ Phenology $\cdot$ Poland $\cdot$ Primeval forest $\cdot$ Climate change

Resale or republication not permitted without written consent of the publisher

\section{INTRODUCTION}

Among the studies of biological impacts of climate warming, those on phenological changes are the most numerous, probably since they are much easier to detect than changes in populations, distributions and community composition (Rosenzweig et al. 2008). Advances in leafing and flowering have been reported from across Europe and North America (e.g. Menzel \& Fabian 1999, Abu-Asab et al. 2001, Fitter \& Fitter 2002, Menzel et al. 2006, Schwartz et al. 2006); these advances can affect changes in the environment with consequences for animals (Post \& Stenseth 1999, Fitter \& Fitter 2002). The onset of spring and summer events, and consequently the length of the growing season, is very sensitive to climate and weather; nearly all spring plant phenophases correlate negatively with temperatures in the preceding 1 to 3 mo (Sparks et al. 2000, Sparks \& Menzel, 2002, Menzel 2003). A growing number of studies where observations include the recent decade of globally warm years have reported phenological advance (reviews in Walther et al. 2002, Root et al. 2003, Schwartz 2003, Badeck et al. 2004, Schwartz et al. 2006, Rosenzweig et al. 2008). However, change in phenology, even in the same species, is not uniform across a species' range (e.g. Tryjanowski et al. 2006). This is likely due to differential warming across the range (Menzel et al. 2006) and differences in latitude (and hence in photoperiod), but also in local adaptation (Tryjanowski et al. 2006).

Phenological recording of plants in Europe has a long history (Nekovar et al. 2008) and is currently concentrated in the hands of state meteorological agencies and focused on species of commercial importance (agricultural and horticultural crops, forest trees) or amenity species associated with human settlements. Far less common are records of species of conservation concern, particularly from pristine environments. Re- 
sults obtained in natural and human-modified habitats may differ in the magnitude of phenological change (Wesołowski \& Rowiński 2006a,b, Delbart et al. 2008), since the latter may be affected by the urban heat island effect (Roetzer et al. 2000) or management influences on habitat structure and soil fertility. In the present study we examine phenological data of native species from a pristine environment.

The Białowieża Forest extends over $1500 \mathrm{~km}^{2}$ across the Poland-Belarus border and includes tracts of primeval lowland temperate forest which are untouched by forestry operations (Faliński 1986, Jędrzejewska \& Jędrzejewski 1998). The forest contains the Białowieża National Park in eastern Poland of $47 \mathrm{~km}^{2}$ (extended to $100 \mathrm{~km}^{2}$ in 1991), which became a strict nature reserve in 1921, since when no hunting, timber harvesting or motor vehicles have been allowed. Its pristine nature has ensured its status as a UNESCO Biosphere Reserve and World Heritage Site. Despite its unique status in Europe, some areas of forest outside the National Park are being exploited for timber.

Records of flowering of 7 , mostly early season, species of woodland herb have been taken from the National Park since 1964. These include species associated with undisturbed habitats (ancient woodland indicators) with low dispersal rates and which are typically associated only with older forests and woodlands. Their low dispersal rates may make them particularly vulnerable to rapid environmental change, such as rising temperatures.

We also refer to a UK dataset which is the only contemporary one we know of containing several of the same species at a similar latitude. We: (1) describe changes in first flowering dates (FFD) and peak flowering dates (PFD) in the 1964-2007 period, (2) examine the potential relationships in FFD and PFD between the study species and (3) identify relationships between timing of flowering and air temperature in Białowieża. Furthermore, we examine some of the species against the UK data to suggest the nature of phenological change in a warmer spring environment.

\section{MATERIALS AND METHODS}

\subsection{Study areas and data sources}

The present study was conducted in the primeval forest stands of the Białowieża National Park, eastern Poland ( $\left.52^{\circ} 42^{\prime} \mathrm{N}, 23^{\circ} 52^{\prime} \mathrm{E}\right)$. The data were mainly collected in oak-lime-hornbeam Tilio-Carpinetum stands characterised by hornbeam Carpinus betulus, smallleaved lime Tilia cordata, pendunculate oak Quercus robur, Norway maple Acer platanoides and Norway spruce Picea abies (Faliński 1986, Tomiałojć 1991, Bobiec et al. 2000). The stands are multi-storey (up to 5 or 6 layers in the Tilio-Carpinetum et al. forest), strongly diverse in terms of the age and size of trees (up to 400-500 yr old, reaching $55 \mathrm{~m}$ height and $720 \mathrm{~cm}$ circumference), and species-rich. Throughout most of its history, the forest was preserved as a royal hunting area.

Observations on FFD and PFD were collected from 1964 and we use data up to 2007 (44 yr). Well-trained observers visited the standard study plot at 5 to $10 \mathrm{~d}$ intervals and noted which herb species (see Table 1) were in flower, the percentage of flowering plants and the development stage of each species. Recording occurred throughout the year and recorder effort was the same throughout the study period. FFD was taken as the date when the first flower of the chosen species was noted and PFD the date when the highest percentage of the chosen herb species flowered simultaneously. Note that flowering records are missing for some years ( 39 to $44 \mathrm{yr}$ of data are present for each species) because recorded flower patches were damaged by foraging animals, especially wild boar Sus scrofa and roe deer Capreolus capreolus.

Local meteorological data (monthly air temperatures) for each year were obtained from the weather station at Białowieża, operating under standard World Meteorological Organization guidelines and situated $1 \mathrm{~km}$ south of the study plot. In the study period average mean monthly temperatures from January to July ranged from -3.9 to $18.8^{\circ} \mathrm{C}$, respectively. The coldest month was January $1987\left(-14.5^{\circ} \mathrm{C}\right)$ and the warmest July $2006\left(22.6^{\circ} \mathrm{C}\right)$.

Table 1. First flowering date (FFD) and peak flowering date (PFD) for 7 woodland herbs in Białowieża National Park. r: Pearson correlation coefficient between FFD and PFD for each species; all are significant at $p<0.001$

\begin{tabular}{|c|c|c|c|c|c|c|c|c|}
\hline & & \multicolumn{3}{|c|}{- FFD } & \multicolumn{3}{|c|}{$-\mathrm{PFD}-$} & \multirow{2}{*}{$\mathrm{r}$} \\
\hline & & $\mathrm{n}$ & Mean & $\mathrm{SD}$ & $\mathrm{n}$ & Mean & $\mathrm{SD}$ & \\
\hline Anemone nemorosa & Wood anemone & 44 & 12 April & 11.1 & 44 & 24 April & 9.2 & 0.70 \\
\hline Hepatica nobilis & Hepatica & 44 & 28 March & 14.5 & 40 & 12 April & 11.0 & 0.82 \\
\hline Oxalis acetosella & Wood sorrel & 44 & 30 April & 8.0 & 44 & 8 May & 8.3 & 0.93 \\
\hline Viola reichenbachiana & Early dog violet & 42 & 1 May & 8.8 & 42 & 11 May & 9.2 & 0.81 \\
\hline Viola riviniana & Common dog violet & 42 & 2 May & 9.2 & 42 & 10 May & 9.7 & 0.92 \\
\hline Lamiastrum galeobdolon & Yellow archangel & 43 & 11 May & 9.6 & 43 & 20 May & 9.1 & 0.89 \\
\hline Maianthemum bifolium & False lily of the valley & 39 & 3 July & 13.2 & 39 & 7 July & 13.7 & 0.98 \\
\hline
\end{tabular}




\subsection{UK data}

For 4 of the species (wood sorrel, early dog violet, common dog violet and yellow archangel), long-term data on FFDs only (1954-2000, recorded by the late R. Fitter) were also available for a similar latitude (c. $51^{\circ} 42^{\prime} \mathrm{N}$ ) from a largely agricultural area in the much milder UK (Fitter \& Fitter 2002). UK monthly temperature data were taken from the Central England series (www.metoffice. gov.uk/research/hadleycentre/obsdata/cet.html). Phenological data for the period 1964-2000 were abstracted for comparison with Białowieża data.

\subsection{Statistical analysis}

All dates were converted to days post-31 December prior to analysis. Previous studies have shown that for the onset of plant spring activity the temperatures of the preceding months are decisive (Sparks et al. 2000, Menzel 2003, Menzel et al. 2005a,b).

Trends over time were determined by linear regression of response variables on year; relationships with temperature were determined using Pearson correlation on individual months' temperatures and multiple linear regression on the 3 monthly temperatures leading up to the mean date of either FFD or PFD. The temperature response of a species was taken as the sum of the 3 monthly coefficients from multiple regression; i.e. the expected change in phenology given a $1^{\circ} \mathrm{C}$ increase in temperature in each month. Slopes of Polish and UK FFDs against temperature were compared using standard regression methods to test equality of slopes. Polish FFD and PFD coefficients were compared using paired $t$-tests.

\section{RESULTS}

\subsection{Temperatures during the study period}

Linear regressions of January to July monthly mean temperatures for Białowieża on year between 1964 and 2007 all produced positive coefficients; those for January, April, May and July were statistically significant at $\mathrm{p}<0.05$. The average coefficient for the 7 months was $0.0610^{\circ} \mathrm{C} \mathrm{yr}^{-1}$, suggesting a $2.7^{\circ} \mathrm{C}$ increase over $44 \mathrm{yr}$.

\subsection{Trends in first flowering dates}

Information on FFD and PFD of the 7 herb species is given in Table 1. Pearson correlations between FFD and PFD were highly significant $(p<0.001)$ for all species. Regressions against year revealed that whilst all trends were negative, i.e. towards earlier flowering, only those for 4 species were significant at $p<0.05$ for FFD and for a different combination of 4 species for PFD (Table 2); 2 others for both FFD and PFD were marginally significant $(0.05<\mathrm{p}<0.10)$. Average trends were $-0.308 \mathrm{~d} \mathrm{yr}^{-1}$ for FFD and $-0.262 \mathrm{~d} \mathrm{yr}^{-1}$ for PFD, representing 14 and $12 \mathrm{~d}$ advances over the $44 \mathrm{yr}$, respectively. A paired $t$-test between trends for FFD and PFD was not significant $\left(t_{6}=-2.01, \mathrm{p}=0.091\right)$. Average FFD and PFD for the 6 earliest species are

Table 2. Summary of the regression of first flowering date (FFD) and peak flowering date (PFD) on year for 7 woodland herbs in Białowieża National Park. The coefficients (b) represent the change $\left(\mathrm{d} \mathrm{yr}^{-1}\right)$ in flowering dates during the period 1964-2007. Values in bold are significant $(p<0.05)$

\begin{tabular}{|c|c|c|c|c|c|c|c|c|}
\hline & \multirow{2}{*}{$\mathrm{b}$} & \multirow{2}{*}{$\begin{array}{l}-\mathrm{FFD} \\
\mathrm{SE}\end{array}$} & \multirow{2}{*}{$\overline{\mathrm{R}^{2}}$} & \multirow[b]{2}{*}{$\mathrm{p}$} & \multirow[b]{2}{*}{$\mathrm{b}$} & \multirow{2}{*}{$\begin{array}{l}-\mathrm{PF} \\
\mathrm{SE}\end{array}$} & \multirow[b]{2}{*}{$\mathrm{R}^{2}$} & \multirow[b]{2}{*}{$\mathrm{p}$} \\
\hline & & & & & & & & \\
\hline Wood anemone & -0.252 & 0.128 & 8.5 & 0.055 & -0.248 & 0.103 & 12.0 & 0.021 \\
\hline Hepatica & -0.330 & 0.166 & 8.6 & 0.054 & -0.250 & 0.134 & 8.3 & 0.071 \\
\hline Wood sorrel & -0.233 & 0.089 & 14.0 & 0.012 & -0.210 & 0.094 & 10.7 & 0.030 \\
\hline Early dog violet & -0.272 & 0.099 & 15.9 & 0.009 & -0.238 & 0.107 & 11.1 & 0.031 \\
\hline Common dog violet & -0.163 & 0.110 & 5.2 & 0.147 & -0.199 & 0.116 & 6.9 & 0.093 \\
\hline Yellow archangel & -0.325 & 0.106 & 18.8 & 0.004 & -0.172 & 0.109 & 5.8 & 0.120 \\
\hline False lily of the valley & -0.582 & 0.149 & 29.2 & $<0.001$ & -0.517 & 0.163 & 21.3 & 0.003 \\
\hline
\end{tabular}

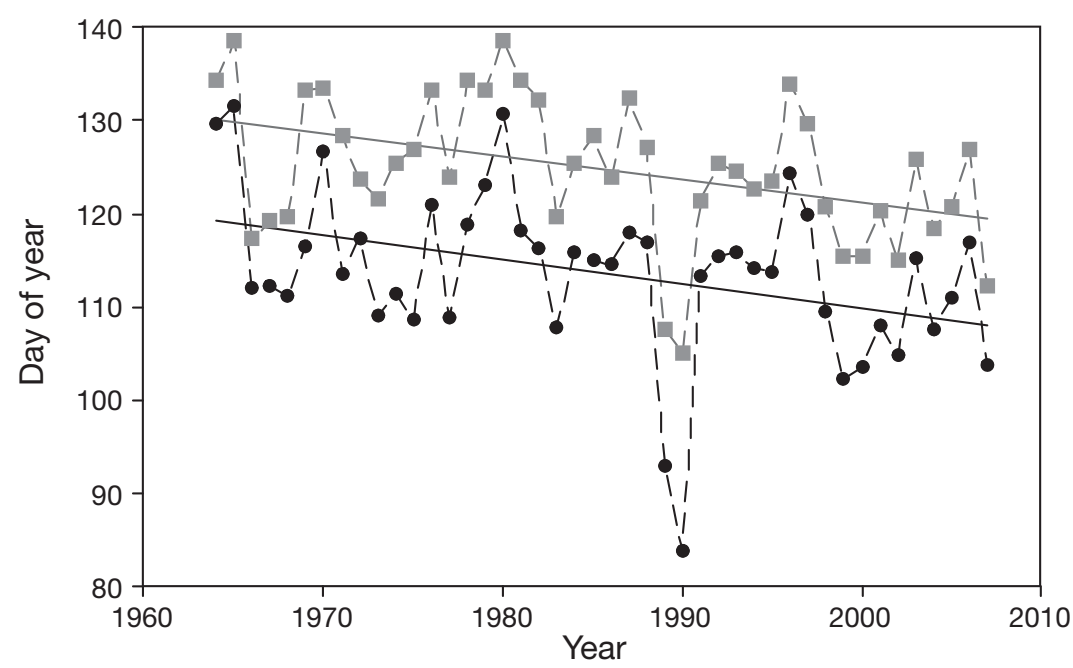

Fig. 1. Mean first (black) and peak (grey) flowering dates for 6 woodland herbs in the Białowieża National Park (wood anemone, hepatica, wood sorrel, early dog violet, common dog violet and yellow archangel; false lily of the valley excluded, because it flowers later). Regression lines superimposed 
Table 3. Pearson correlations between monthly mean air temperatures and first flowering date (FFD) and peak flowering date (PFD) of 7 woodland herbs in Białowieża National Park. Only months up to and including the month in which the mean date occurred are shown. Values in bold are significant at $\mathrm{p}<0.05$. Shaded boxes indicate the largest correlation for each species/phase.

Neither of the July correlations with false lily of the valley (FFD -0.12; PFD -0.09) were significant and are not shown

\begin{tabular}{|c|c|c|c|c|c|c|c|c|c|c|c|c|}
\hline & \multirow[b]{2}{*}{ Jan } & \multirow[b]{2}{*}{ Feb } & \multicolumn{2}{|c|}{ FFD } & \multirow[b]{2}{*}{ May } & \multirow[b]{2}{*}{ Jun } & \multirow[b]{2}{*}{ Jan } & \multirow[b]{2}{*}{ Feb } & \multirow{2}{*}{$\begin{array}{l}-\mathrm{PF} \\
\text { Mar }\end{array}$} & \multirow[b]{2}{*}{ Apr } & \multirow[b]{2}{*}{ May } & \multirow[b]{2}{*}{ Jun } \\
\hline & & & Mar & Apr & & & & & & & & \\
\hline Wood anemone & -0.43 & -0.51 & -0.76 & -0.46 & & & -0.33 & -0.47 & -0.58 & -0.61 & & \\
\hline Hepatica & -0.55 & -0.63 & -0.78 & & & & -0.53 & -0.59 & -0.69 & -0.48 & & \\
\hline Wood sorrel & -0.53 & -0.61 & -0.66 & -0.63 & & & -0.51 & -0.47 & -0.70 & -0.62 & -0.29 & \\
\hline Early dog violet & -0.44 & -0.44 & -0.53 & -0.66 & -0.25 & & -0.44 & -0.51 & -0.50 & -0.59 & -0.28 & \\
\hline Common dog violet & -0.39 & -0.48 & -0.50 & -0.54 & -0.28 & & -0.44 & -0.51 & -0.54 & -0.55 & -0.35 & \\
\hline Yellow archangel & -0.39 & -0.49 & -0.60 & -0.74 & -0.46 & & -0.41 & -0.31 & -0.60 & -0.66 & -0.50 & \\
\hline False lily of the valley & -0.25 & 0.04 & -0.24 & -0.43 & -0.52 & -0.37 & -0.15 & 0.10 & -0.21 & -0.37 & -0.50 & -0.34 \\
\hline
\end{tabular}

plotted in Fig. 1; false lily of the valley was omitted from this mean because it flowers much later than the other species.

\subsection{Influence of temperature on FFD and PFD}

Correlations between first and peak flowering dates and temperature for the January to July period are given in Table 3. In general, both FFD and PFD had the strongest correlations with March and April temperatures.

Multiple regressions of flowering dates against the temperatures of the immediately preceding 3 months are summarised in Table 4 . All series produced significant relationships with temperature in at least 1 month, and models explained between 34.3 and $68.3 \%$ of the variation in FFD and between 30.6 and $63.9 \%$ of the variation in PFD. Responses to temperature varied be- tween 4 and $6 \mathrm{~d}^{\circ} \mathrm{C}^{-1}$ for both FFD and PFD. There was no significant consistent difference between FFD and PFD temperature responses (paired $t$-test, $t_{6}=-0.79, \mathrm{p}$ $=0.461$ ), but models for FFD explained significantly more variation than those for $\operatorname{PFD}\left(t_{6}=2.74, \mathrm{p}=0.034\right)$.

\subsection{Comparison of Polish and UK FFD}

Flowering occurred significantly earlier in the UK than in Poland (Table 5). Responses to temperature were much greater in the UK (Fig. 2); the 3 mo period used for graphing has been selected as intermediate between Polish and UK flowering dates. A comparison of regression slopes in Fig. 2 indicates a significantly steeper slope in the UK for wood sorrel $\left(F_{1,76}=14.99\right.$, $\mathrm{p}<0.001)$, early dog violet $\left(F_{1,73}=29.17, \mathrm{p}<0.001\right)$ and common dog violet $\left(F_{1,73}=11.62, \mathrm{p}=0.001\right)$, but not for yellow archangel $\left(F_{1,73}=1.31, \mathrm{p}=0.26\right)$.

Table 4. Summary of multiple regression models of first flowering date (FFD) and peak flowering date (PFD) of 7 woodland herbs in Białowieża National Park on the 3 monthly mean temperatures up to and including the month in which the mean date occurred. Regression coefficients $\left(\mathrm{d}^{\circ} \mathrm{C}^{-1}\right)$ in bold are individually significant $(p<0.05)$. The final 3 columns sum the coefficients and present the variability explained by the model $\left(\mathrm{R}^{2}\right)$ and the overall model significance

\begin{tabular}{|c|c|c|c|c|c|c|c|c|c|c|}
\hline & Jan & Feb & Mar & Apr & May & Jun & Jul & Sum & $\mathrm{R}^{2}$ & $\mathrm{p}$ \\
\hline \multicolumn{11}{|l|}{ FFD } \\
\hline Wood anemone & & -0.36 & -2.72 & -1.41 & & & & -4.49 & 62.8 & $<0.001$ \\
\hline Hepatica & -0.42 & -1.17 & -3.19 & & & & & -4.78 & 68.3 & $<0.001$ \\
\hline Wood sorrel & & -0.70 & -1.06 & -2.16 & & & & -3.92 & 67.7 & $<0.001$ \\
\hline Early dog violet & & & -1.13 & -3.11 & 0.22 & & & -4.02 & 52.9 & $<0.001$ \\
\hline Common dog violet & & & -1.22 & -2.47 & -0.04 & & & -3.73 & 39.2 & $<0.001$ \\
\hline Yellow archangel & & & -1.43 & -3.49 & -0.89 & & & -5.81 & 71.0 & $<0.001$ \\
\hline False lily of the valley & & & & & -3.55 & -2.87 & 0.00 & -6.42 & 34.3 & 0.002 \\
\hline \multicolumn{11}{|l|}{ PFD } \\
\hline Wood anemone & & -0.46 & -1.14 & -2.61 & & & & -4.21 & 54.0 & $<0.001$ \\
\hline Hepatica & & -0.90 & -1.98 & -1.77 & & & & -4.65 & 60.3 & $<0.001$ \\
\hline Wood sorrel & & & -1.74 & -2.25 & 0.04 & & & -3.95 & 63.9 & $<0.001$ \\
\hline Early dog violet & & & -1.12 & -2.76 & -0.09 & & & -3.97 & 43.7 & $<0.001$ \\
\hline Common dog violet & & & -1.38 & -2.48 & -0.41 & & & -4.27 & 43.8 & $<0.001$ \\
\hline Yellow archangel & & & -1.45 & -2.69 & -1.18 & & & -5.32 & 65.2 & $<0.001$ \\
\hline False lily of the valley & & & & & -3.56 & -2.79 & 0.24 & -6.11 & 30.6 & 0.005 \\
\hline
\end{tabular}


Table 5. Comparison of first flowering date (FFD) in Poland and the UK for 4 forest herbs. n: number of common years of data; diff: number of days earlier that FFD occurred in the UK; sum(UK): sum of the 3 monthly temperature coefficients for the UK (approach as for Poland in Table 4)

\begin{tabular}{|lrrrrr|}
\hline & $\mathrm{n}$ & diff & \multicolumn{1}{c}{$t$} & $\mathrm{p}$ & Sum(UK) \\
\hline Wood sorrel & 36 & 20 & 10.17 & $<0.001$ & -7.6 \\
Early dog violet & 33 & 34 & 13.22 & $<0.001$ & -10.8 \\
Common dog violet & 33 & 23 & 14.51 & $<0.001$ & -5.4 \\
Yellow archangel & 33 & 6 & 2.23 & 0.033 & -7.2 \\
\hline
\end{tabular}

\section{DISCUSSION}

The present study revealed strong correlations between first and peak flowering dates and temperature for all study herbs in the primeval forest of Białowieża National Park. The former is typically much easier to record, but changes in FFD do not seriously misrepresent changes in PFD. Changes in the flowering phenology of forest floor herbs in this pristine environment as a consequence of rising temperatures appear to be as great as those reported more widely in Europe (Menzel et al. 2006).

As with other studies (Sparks et al. 2000, Sparks \& Menzel 2002, Menzel 2003), the temperatures of the immediately preceding months appear to be those driving phenological change. Whilst every effort has been made in the past to insulate the Białowieża National Park from human influence, it is clear that it cannot escape the effects of a globally changing climate. The changing phenology of these woodland herbs will also affect other species reliant on them, for example the violet-feeding fritillary butterflies, unless phenological synchrony is maintained in all trophic levels (Harrington et al. 1999). Most susceptible to asynchronous changes will be those species reliant on one or a small number of other species where sufficient phenological overlap is necessary to ensure survival.

Unlike the Poland data, the UK data were not collected in such a pristine environment; Białowieża is unique in Europe. The UK flowering dates were significantly earlier than in Poland, despite experiencing very similar day length regimes (see also Tryjanowski et al. 2006), presumably because of much milder temperatures (see Fig. 2). It is not quite so obvious why they had a significantly greater temperature response than in Poland. We suggest 3 possibilities: (1) Białowieża plants may be more insulated by the high and multilayered canopy; (2) the species may be adapted to local climatological conditions (e.g. UK is less prone to severe frosts); and (3) the response to temperature may not be linear over a wider range of temperatures (see also Sparks et al. 2000).
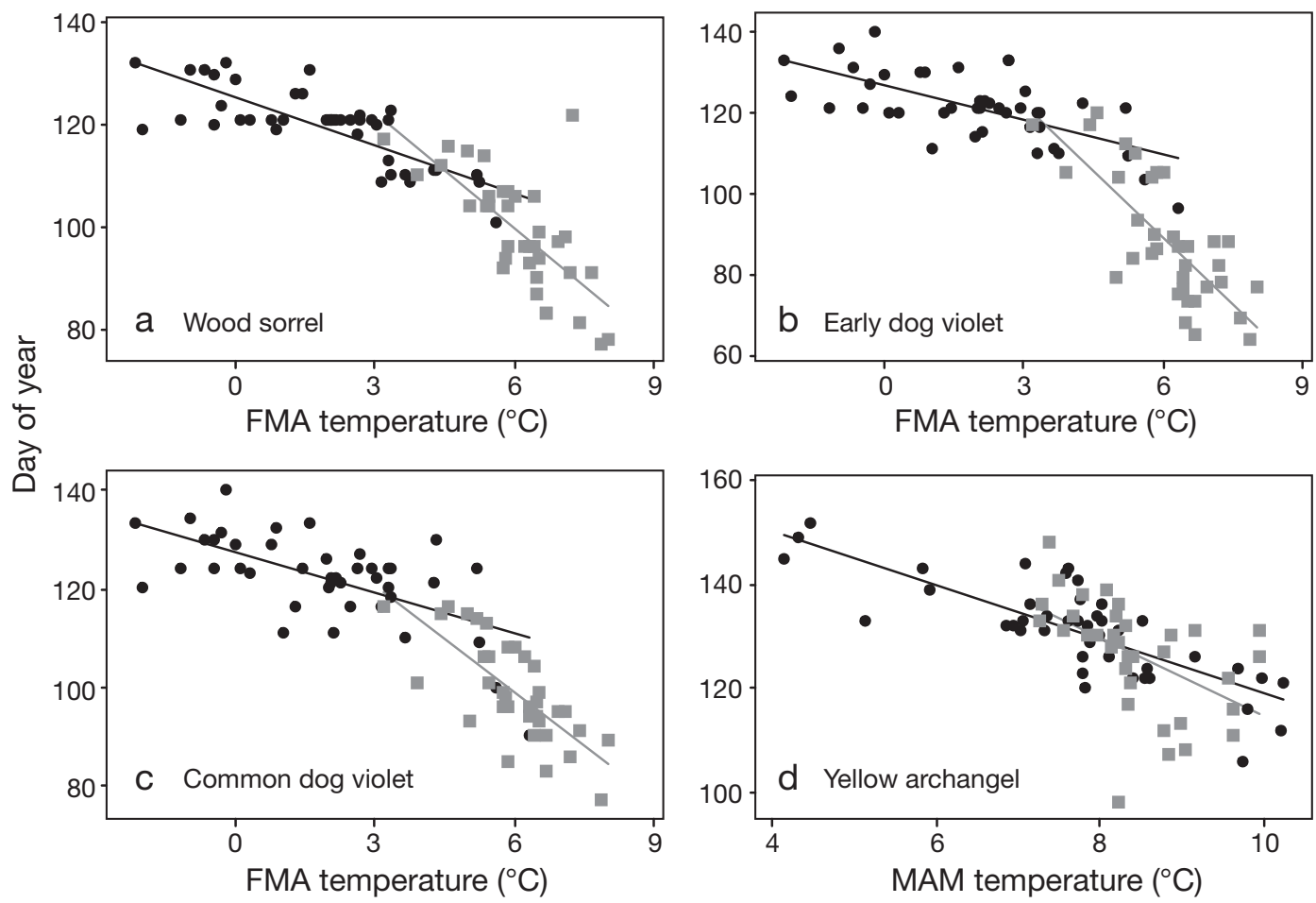

Fig. 2. Relationships between Polish (black) and UK (grey) first flowering dates and temperature for: (a) wood sorrel, (b) early dog violet, (c) common dog violet and (d) yellow archangel; (a-c) February to April (FMA), (d) March to May (MAM). Polish phenology and temperature data from Białowieża National Park, UK phenology data from Fitter \& Fitter (2002) and UK temperatures from Central England series. Regression lines shown 
An examination of Fig. 2 suggests that this third explanation may have some merit. Where temperatures of the 2 countries overlap, flowering appears to occur at similar dates (i.e. UK flowering may not be inherently earlier than in Poland under the same conditions). If this argument has any credence it suggests that the Polish temperature responses in Table 4, calculated by linear regression methods on monthly temperatures, seriously underestimate changes that may occur in the future as Polish temperatures in spring rise to meet those currently experienced in the UK. Thus advances in flowering phenology may become much more rapid than currently experienced, creating potential problems for conservation. Experimental studies of plants from different origins and under a wide range of controlled temperatures may be necessary to test the validity of these 3 suggestions.

Białowieża is a very unique environment, but it is clear that climate change is starting to affect its natural capital. If changes in phenology are asynchronous between different elements of a food web, then the continued co-existence of those species may be affected. Species most likely to be affected are those reliant on one or a small number of species. Furthermore, species characteristic of ancient woodlands typically have limited dispersal abilities and may not be able, if needed, to relocate to a new environment as a consequence of their existing locations becoming climatically unsuitable.

Acknowledgements. We thank the late Prof. J. Faliński for starting and developing the phenological program in Białowieża, and the paper is dedicated to his memory. The authors also thank T. Borowik for assistance with obtaining temperature data. The data analysis was supported by a grant from the Polish Ministry of Science no. N304 039 31/1317. The manuscript has benefited from the comments of 2 anonymous reviewers.

\section{LITERATURE CITED}

Abu-Asab MS, Peterson PM, Shetler SG, Orli SS (2001) Earlier plant flowering in spring as a response to global warming in the Washington, DC, area. Biodivers Conserv 10:597-612

Badeck FW, Bondeau A, Böttcher K, Doktor D, Lucht W, Schaber J, Sitch S (2004) Responses of spring phenology to climate change. New Phytol 162:295-309

Bobiec A, van der Burgt H, Meijer K, Zuyderduyn C (2000) Rich deciduous forests in Białowieza as a dynamic mosaic of developmental phases: premises for nature conservation and restoration management. For Ecol Manage 130: 159-175

Delbart N, Picard G, Le Toan T, Kergoat L and others (2008) Spring phenology in boreal Eurasia over a nearly century time scale. Glob Change Biol 14:603-614

Faliński JB (1986) Vegetation dynamics in temperate forests (ecological studies in Białowieża Forest). W Junk, Dordrecht

Fitter AH, Fitter RSR (2002) Rapid changes in flowering time in British plants. Science 296:1689-1691

Harrington R, Woiwod I, Sparks T (1999) Climate change and trophic interactions. Trends Ecol Evol 14:146-150

Jędrzejewska B, Jędrzejewski W (1998) Predation in vertebrate communities: the Białowieża Primeval Forest as a case study. Springer-Verlag, Berlin

Menzel A (2003) Plant phenological anomalies in Germany and their relation to air temperature and NAO. Clim Change 57:243-263

Menzel A, Fabian P (1999) Growing season extended in Europe. Nature 397:659

Menzel A, Estrella N, Testka A (2005a) Temperature response rates from long-term phenological records. Clim Res 30: $21-28$

> Menzel A, Sparks TH, Estrella N, Eckhardt S (2005b) 'SSW to NNE' - North Atlantic Oscillation affects the progress of seasons across Europe. Glob Change Biol 11:909-918

> Menzel A, Sparks TH, Estrella N, Koch E, and others (2006) European phenological response to climate change matches the warming pattern. Glob Change Biol 12:1969-1976

Nekovar J, Koch E, Kubin E, Nejedlik P, Sparks T, Wielgolaski FE (eds) (2008) The history and current status of plant phenology in Europe. COST Action 725. COST, Brussels

Post E, Stenseth NC (1999) Climatic variability, plant phenology, and northern ungulates. Ecology 80:1322-1339

Roetzer T, Wittenzeller M, Haeckel H, Nekovar J (2000) Phenology in central Europe - differences and trends of spring phenophases in urban and rural areas. Int J Biometeorol 44:60-66

Root TL, Price JT, Hall KR, Schneider SH, Rosenzweig C, Pounds JA (2003) Fingerprints of global warming on wild animals and plants. Nature 421:57-60

> Rosenzweig C, Karoly D, Vicarelli M, Neofotis P and others (2008) Attributing physical and biological impacts to anthropogenic climate change. Nature 453:353-358

Schwartz MD (ed) (2003) Phenology: an integrative environmental science. Kluwer, Dordrecht

Schwartz MD, Ahas R, Aasa A (2006) Onset of spring starting earlier across the Northern Hemisphere. Glob Change Biol 12:343-351

Sparks TH, Menzel A (2002) Observed changes in seasons: an overview. Int J Climatol 22:1715-1725

Sparks TH, Jeffree EP, Jeffree CE (2000) An examination on the relationship between flowering times and temperature at the national scale using long-term phenological records from the UK. Int J Biometeorol 44:82-87

Tomiałojć L (1991) Characteristics of old growth in the Białowieża Forest, Poland. Nat Areas J 11:7-18

> Tryjanowski P, Panek M, Sparks T (2006) Phenological response of plants to temperature varies at the same latitude: case study of dog violet and horse chestnut in England and Poland. Clim Res 32:89-93

- Walther GR, Post E, Convey P, Menzel A and others (2002) Ecological responses to recent climate change. Nature 416:389-395

Wesołowski T, Rowiński P (2006a) Timing of bud burst and tree-leaf development in a multispecies temperate forest. For Ecol Manage 237:387-393

Wesołowski T, Rowiński P (2006b) Tree defoliation by winter moth Operophtera brumata L. during an outbreak affected by structure of forest landscape. For Ecol Manage 221:299-305 